\title{
DEVELOPMENT OF THE ORIGINAL METHOD FOR DETERMINATION OF DICLOFENAC SODIUM IN DIFFERENT DRUG DOSAGE FORMS
}

\author{
V.A.Khanin, O.M.Kotenko, O.O.Moiseev, O.V.Dorovskyy \\ LLC Pharmaceutical Company "Zdorovye" \\ Ivan Kozhedub Kharkiv University of Air Force \\ National University of Pharmacy
}

Key words: diclofenac sodium; high-performance liquid chromatography; quantitative determination; validation

\begin{abstract}
There are a number of methods for determination of diclofenac sodium in medicines; however, they all differ by analytical methods involved depending on the drug dosage form. The aim of the study was to develop the universal HPLC-method for determination of diclofenac sodium, which would be suitable for quantitative determination of this active pharmaceutical ingredient (API) in various dosage forms. In our study a chromatograph 2695 with a photodiode array detector 2996 (Waters Corp., USA) and the column containing the C18 phase with the particle size of $5 \mathrm{~mm}$, ER-182 balances (AND company, Japan), measuring glassware of class A were used. Validation of the method has been conducted in accordance with the requirements of the State Pharmacopoeia of Ukraine (SPhU). The HPLC-method for determination of diclofenac sodium in different drug dosage forms and UPLCvariant of this method for conducting rapid measurements have been developed. Validation of the methods proposed has been conducted, their suitability for determining diclofenac sodium in different drug dosage forms, as well as the insignificant effect of the sample preparation on the analysis results have been proven. The analysis of various medicines has been performed; the possibility of using the methods developed for the analysis of existing medicines based on diclofenac sodium has been proven.
\end{abstract}

Among medicines used in the treatment of inflammations non-steroidal anti-inflammatory drugs (NSAIDs) are one of the most important pharmacological groups. Among the compounds of this series there is diclofenac sodium, a highly effective NSAID, which is widespread at the pharmaceutical market. More than thirty different names of finished medicinal products, in which diclofenac sodium is the active pharmaceutical ingredient (API), are known [2].

Diclofenac sodium has the anti-inflammatory, analgesic and antipyretic effects. By the intensity of the antiinflammatory action it is similar to indomethacin, and by its mechanism of action - to ibuprofen. It has no effect on the body weight, blood pressure and pulse. Diclofenac sodium inhibits the activity of the enzyme cyclooxygenase; as a result, the synthesis of prostaglandins playing a key role in development of inflammatory reactions is disturbed.

Diclofenac sodium is used in rheumatoid arthritis, rheumatism, ankylosing spondylitis (Bekhterev's disease), arthrosis, spondylarthrosis; other inflammatory diseases of the joints, postoperative and post-traumatic edemas, neuralgia, pain syndromes of different genesis (including primary dysmenorrhea); when treating infectious inflammatory diseases of ENT organs in the acute phase $[3,6,8]$.

The most common pharmaceutical forms and presentation of diclofenac sodium are gastro-resistant tablets (0.025-0.05 g), 2.5\% solution for injection in ampoules of $3 \mathrm{ml}$ and $1 \%$ gel. In addition to the gel with diclofenac sodium the gel with diclofenac diethylamine is also manufactured. Diclofenac sodium is also used in rectal suppositories and eye drops in the form of $0.1 \%$ solution.

Currently there are many methods for determination of diclofenac sodium in medicines; however, all these methods differ by analytical methods involved depending on the drug dosage form - acidimetry for a substance in non-aqueous media, spectrophotometry for tablets and ointments, the extraction-spectrophotometric method for tablets, high-performance thin-layer chromatography for the blood plasma and high-performance liquid chromatography HPLC) for injection dosage forms. The drawback of this diversity of analytical methods is the lack of versatility of each specific method, and it does not allow applying the same analytical method to the analysis of different dosage forms. In this respect the HPLCmethod potentially has the greatest versatility since the high selectivity of the chromatographic method will allow eliminating components of placebo regardless of the form of the medicine $[4,5,7,9,10]$.

The aim of the study was to develop the universal HPLC-method for determination of diclofenac sodium, which would be suitable for quantitative determination of this API in various dosage forms.

Materials and Methods

Diclofenac sodium is 2-(2-(2,6-dichlorophenylamino) phenyl)acetic acid (in the form of sodium salt) (Sheme). 


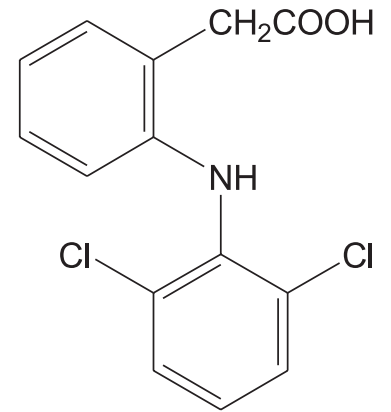

Sheme. The empirical formula $\mathrm{C}_{14} \mathrm{H}_{11} \mathrm{Cl}_{2} \mathrm{NO}_{2}$.

It is a white or slightly yellowish crystalline powder, slightly hygroscopic, readily soluble in methanol, acetone, sparingly soluble in water, practically insoluble in ether. It can be hydrolyzed; in addition, formation of a light suspension is observed. It melts at $280^{\circ} \mathrm{C}$ with decomposition.

The following equipment was used: a chromatograph 2695 with a photodiode array detector 2996 (Waters Corp., USA), the column containing the $\mathrm{C} 18$ phase with the particle size of $5 \mu \mathrm{m}$, ER-182 balances (AND company, Japan), and measuring glassware of class A.

Before carrying out the main validation tests the availability of the documents testifying to the suitability of the equipment, raw material and reagents used was controlled.

Validation of the method has been conducted in accordance with the requirements of the SPhU [1].

\section{Results and Discussion}

At the first stage the HPLC-method was developed for use in the normal splitting mode. The validation of the method developed was also conducted, and its suitability for quantitative determination of diclofenac sodium in different drug dosage forms was proven.

The chromatographic procedure was performed in the following conditions:

- the column with the size of $250 \times 4.6 \mathrm{~mm}$ filled with octadecylsilyl silica gel for chromatography $R$ with the particle size of $5 \mu \mathrm{m}$ or the similar one, for which the requirements of the System Suitability Test are met;

- mobile phase A: anhydrous formic acid $R$-water $R$ (0.5:500) degassed by any convenient way;

- mobile phase B: anhydrous formic acid $R$ - acetonitrile for chromatography $R(0.5: 250)$ degassed by any convenient way;

- the mobile phase rate $-1 \mathrm{ml} / \mathrm{min}$;

- the following gradient programme was used:

\begin{tabular}{|c|c|c|c|}
\hline Time, min & $\begin{array}{c}\text { MP A, \% } \\
\text { vol/vol }\end{array}$ & $\begin{array}{c}\text { MP B, \% } \\
\text { vol/vol }\end{array}$ & $\begin{array}{c}\text { The elution } \\
\text { mode }\end{array}$ \\
\hline 0 & 80 & 20 & Isocratic mode \\
\hline $0 \rightarrow 20$ & $80 \rightarrow 35$ & $20 \rightarrow 65$ & Linear gradient \\
\hline $20 \rightarrow 21$ & $35 \rightarrow 80$ & $65 \rightarrow 20$ & Linear gradient \\
\hline $21 \rightarrow 25$ & 80 & 20 & Isocratic mode \\
\hline
\end{tabular}

- the column temperature $-30^{\circ} \mathrm{C}$;

- the wavelength $-254 \mathrm{~nm}$;

- the injection volume $-10 \mu \mathrm{l}$.
To work with high-speed liquid chromatographs the UPLC-version of the method was developed; it allowed reducing the injection time to $2 \mathrm{~min}$.

UPLC-version of the method:

- the column with the size of $100 \times 4.6 \mathrm{~mm}$ filled with a sorbent with the stationary phase of octadecylsilyl silica gel for chromatography $R$ or the similar one, for which the requirements of the System Suitability Test are met;

- mobile phase A: anhydrous formic acid $R$-water $\mathrm{R}(0.5: 500)$ degassed by any convenient way;

- mobile phase B: anhydrous formic acid R - acetonitrile for chromatography $R(0.5: 250)$ degassed by any convenient way;

- the mobile phase rate $-3 \mathrm{ml} / \mathrm{min}$;

- the following gradient programme was used:

\begin{tabular}{|c|c|c|c|}
\hline Time, $\min$ & $\begin{array}{c}\text { MP A, \% } \\
\text { vol/vol }\end{array}$ & $\begin{array}{c}\text { MP B, \% vol/ } \\
\text { vol }\end{array}$ & The elution mode \\
\hline 0 & 80 & 20 & Isocratic mode \\
\hline $0 \rightarrow 1$ & $80 \rightarrow 35$ & $20 \rightarrow 65$ & Linear gradient \\
\hline $1 \rightarrow 1.5$ & $35 \rightarrow 80$ & $65 \rightarrow 20$ & Linear gradient \\
\hline $1.5 \rightarrow 2$ & 80 & 20 & Isocratic mode \\
\hline
\end{tabular}

- the column temperature $-30^{\circ} \mathrm{C}$;

- the wavelength - $254 \mathrm{~nm}$.

- the injection volume $-20 \mu \mathrm{l}$.

Based on the HPLC-method developed with the gradient mode of elution the following medicines of LLC Pharmaceutical company "Zdorovye" were analyzed: Diclocain-Zdorovye, solution for injection; Diclofenac-Zdorovye, $1 \%, 3 \%$ and $5 \%$ gel; Ortophen-Zdorovye, filmcoated tablets containing diclofenac sodium in combination with other API.

When developing the method it was found that the conditions of chromatography chosen allowed determining not only diclofenac sodium, but also such substances as benzyl alcohol, lidocaine, nipagin and nipasol included in these drugs.

Our results of quantitative determination of diclofenac sodium in medicines according to the above method demonstrate its reproducibility.

Verification of the method for quantitative determination of diclofenac sodium was carried out by such validation characteristics as specificity, linearity, convergence, precision, accuracy and intermediate precision.

When conducting validation of the method it was proven that the sample preparation had the insignificant effect on the result of quantitative determination of diclofenac sodium irrespective of the drug dosage form, therefore, the sample preparation was not performed.

Since HPLC is specific in the method used, to prove the specificity of the method it is sufficient to meet all requirements to the criteria of linearity, convergence, precision, accuracy and intermediate precision.

Linearity of the method was assessed within the whole range of the method application by the method of standard. The study of the dependence of the optical density on the concentration was performed using 9 model solutions for analysis with the concentrations of 10, 20, 40, $60,80,100,140,180$ and $210 \%$. 
Characteristics of the linear dependence

\begin{tabular}{|l|c|c|c|c|}
\hline \multicolumn{1}{|c|}{ Parameters } & Values & Requirements 1 & Requirements 2 & Conclusion \\
\hline $\mathrm{b}$ & 1.005014 & & & \\
\hline $\mathrm{Sb}$ & 0.0033776273 & & & \\
\hline $\mathrm{a}$ & $|-0.22252903|$ & $<=|0.71113478|$ & $<=|5.6579048|$ & the first criterion is met \\
\hline $\mathrm{Sa}$ & 0.38243333 & & & \\
\hline $\mathrm{RSD}_{0}$ & 0.67417305 & & & met \\
\hline $\mathrm{RSD}_{0} / \mathrm{b}$ & $|0.6708096|$ & $<=|8.6044636|$ & & met \\
\hline $\mathrm{RSD}_{\mathrm{y}}$ & 70.78 & & & \\
\hline $\mathrm{r}$ & $|0.99995464|$ & $>|0.99258331|$ & & \\
\hline
\end{tabular}

Note: Student $(95,1,8)=1.8595$. Conclusion: the requirements to linearity are met.

Table 2

The results of analysis for model solutions and their statistical processing

\begin{tabular}{|c|c|c|c|c|c|c|c|c|}
\hline $\begin{array}{c}\text { Test } \\
\text { solutions }\end{array}$ & Name & Mean $\mathrm{S}_{\mathrm{i}}$ & $\mathrm{C}_{\mathrm{i}}$ & $\mathrm{S}_{\mathrm{ir}}$ & $\mathrm{C}_{\mathrm{ir}}$ & $\mathrm{RSD}_{\mathrm{i}}$ & $\mathrm{S}_{\mathrm{ir}} / \mathrm{C}_{\mathrm{ir}} \times 100$ & $\mathrm{~S}_{\mathrm{y}} \times \mathrm{t}$ \\
\hline 1 & $\mathrm{RS}$ & 100.005 & 100 & 100 & 100 & 0.007071 & 100 & 0.39821804 \\
\hline 2 & $\mathrm{M} 1$ & 10.16 & 10 & 10.159492 & 10 & 0.696 & 101.59492 & 0.65992175 \\
\hline 3 & $\mathrm{M} 2$ & 20.37 & 20 & 20.368982 & 20 & 1.1802 & 101.84491 & 0.61087658 \\
\hline 4 & $\mathrm{M} 3$ & 40.465 & 40 & 40.462977 & 40 & 0.2971 & 101.15744 & 0.52171395 \\
\hline 5 & $\mathrm{M} 4$ & 59.29 & 60 & 59.287036 & 60 & 0.3101 & 98.811726 & 0.45028706 \\
\hline 6 & $\mathrm{M} 5$ & 80.245 & 80 & 80.240988 & 80 & 0.2555 & 100.30123 & 0.40606546 \\
\hline 7 & $\mathrm{M} 6$ & 99.13 & 100 & 99.125044 & 100 & 0.214 & 99.125044 & 0.39821804 \\
\hline 8 & $\mathrm{M} 7$ & 141.04 & 140 & 141.03295 & 140 & 0.2106 & 100.73782 & 0.49053819 \\
\hline 9 & $\mathrm{M} 8$ & 180.265 & 180 & 180.25599 & 180 & 0.3099 & 100.14222 & 0.67000653 \\
\hline 10 & $\mathrm{M} 9$ & 211.565 & 210 & 211.55442 & 0.17714 & 210 & 100.7402 & 0.82943268 \\
\hline
\end{tabular}

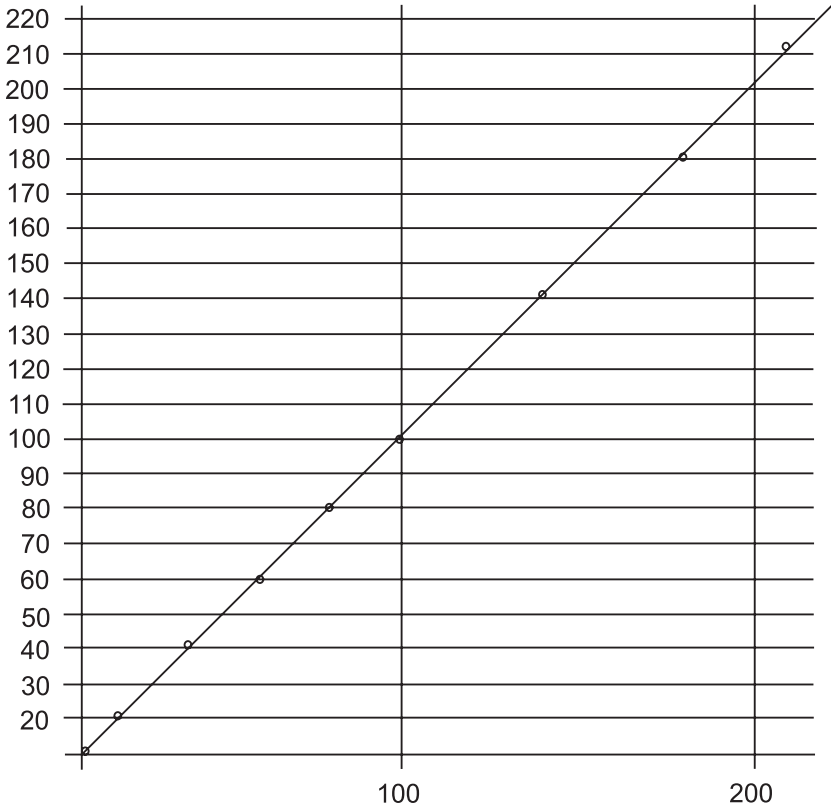

Fig. The linear dependence of the peak area on the concentration of diclofenac sodium in the normalized coordinates.

The results obtained were statistically processed by the least square method according to the requirements of the SPhU.

In our case the requirements to the linear dependence parameters were performed within the whole range of the method application (10-210\%) (Fig., Tab. 1).
To conduct measurements and calculation of metrological estimation of convergence and accuracy of the method three values of peak areas for the reference solution and 27 values of peak areas for model solutions were obtained. Actual values $\left(X i_{a c t}\right)$, the ratio of average values of the peak areas for each of 27 solutions to the average value of the peak area of the reference solution were calculated, getting values $X_{i}=\left(C_{i} / C_{s}\right) \times 100 \%, Y_{i}=$ $\left(S_{i} / S_{s}\right) \times 100 \%$, as well as value $Z_{i}=\left(Y_{i} / X_{j}\right) \times 100 \%$ representing the concentration found (\%) to the concentration introduced. The results of calculations are given in Tab. 2.

To assess the intermediate precision the relative confidence interval for 5 parallel measurements of the quantitative content of substances was used, it should be less than maximum acceptable uncertainty of the results of the analysis: $\Delta_{z} \leq 1.6 \%$. Tests were performed by different analysts using one batch of the medicine on the same chromatograph in different days and using different measuring glassware.

The intermediate precision was confirmed by the fact that the value of the relative confidence interval for five parallel measurements of one batch of the drug satisfied the acceptance criterion $\left(\Delta_{\mathrm{z}}=0.22 \% \leq 1.6 \%\right)$.

\section{CONCLUSIONS}

1. The HPLC-method for determination of diclofenac sodium in different drug dosage forms and UPLCvariant of this method for conducting rapid measurements have been developed. 
2. Validation of the methods proposed has been conducted, their suitability for determining diclofenac sodium in different drug dosage forms, as well as the insignificant effect of the sample preparation on the analysis result have been proven.

3. According to the methods developed the analysis of various medicines, in which diclofenac sodium is the active substance (or one of the active substances), has been performed. An excellent separation of diclofenac sodium peaks with peaks of other components of the drug has been determined, and it proves the possibility of using the methods developed for the analysis of existing medicines based on diclofenac sodium.

\section{REFERENCES}

1. Державна фармакопея України: в 3-х m. / Державне підприємство «Украйнський науковий фармакопейний центр якості лікарських засобів». - 2-е вид. - Х.: Державне підприємство «Украӥнський науковий фармакопейний центр якості лікарських засобів», 2015. - T. 1. - $1128 \mathrm{c}$.

2. Довідник лікарських засобів, зареєстрованих в Україні [Електронний ресурс]. - Режсим доступу: https:// medhub.info/31246dcb

3. Каратеев А.Е., Насонов Е.Л., Яхно Н.Н. и др. // Современная ревматол. - 2015. - №1. - С. 4-23.

4. Симонян А.В., Яковлева Н.И. // Вестник ВолгГМУ. - 2015. - Вып. 4(56). - С. 102-104.

5. Степанова Э.Ф., Саенко А.Ю., Петров А.Ю. и др. // Фундаментальные исследования. - 2013. - №10-12. C. 2710-2714.

6. Baraf H.S., Gloth F.M., Barthel H.R. et al. // Drugs Aging. - 2011. - №28(1). - P. 27-40.

7. European Pharmacopoeia. - 8-th ed. - Strasbourg: European Directorate for the Quality of Medicines, Council of Europe, 2013. - 3655 p.

8. Harirforoosh S., Asghar W., Jamali F. // J. Pharm. Pharm. Sci. - 2013. - №16(5). - P. 821-847.

9. Moiseev O.O., Dorovskoi O.V., Khanin V.A. et al. // Вісник фармачіï. - 2013. - №4. - C. 19-22.

10. The United State Pharmacopeia: 37 -NF32. - Rockville: The United State Pharmacopeia, Inc., 2014. - 3503 p.

РОЗРОБКА ОРИГІНАЛЬНОЇ МЕТОДИКИ ВИЗНАЧЕННЯ ДИКЛОФЕНАКУ НАТРІЮ В РІЗНИХ ФОРМАХ ЛІКАРСЬКИХ ПРЕПАРАТІВ

В.А.Ханін, О.М.Котенко, О.О.Моїсеєв, О.В.Доровський

Ключові слова: диклофенак натрію; високоефективна рідкісна хроматография; кількісне визначення; валідація

На сьогодні існує низка методик визначення диклофренаку натрію в лікарських препаратах, однак в них задіяні різні аналітичні методи залежно від лікарської форми препарату. Метою даного дослідження стала розробка універсальної BEPX-методики визначення диклофенаку натрію, яка може застосовуватись для кількісного визначення иього АФІ в різних лікарських формах. У дослідженнях використовували хроматограф 2695 з діодноматричним детектором 2996 фрірми Waters Corp. USA з колонкою, яка містить фразу C18 з розміром часток 5 мм, ваги ER-182 фірми AND Japan, мірний посуд класу A. Валідація методики проводилась відповідно до вимог ДФУ. Розроблена ВЕРX-методика визначення диклофенаку натрію в різних лікарських формах ma UPLC-варіант иієї методики для проведення експрес-вимірювань. Проведена валідація запропонованих методик, доведена їх придатність для визначення диклофренаку натрію в різних лікарських формах та несуттєвий вплив пробопідготовки на результати аналізу. Проведено аналіз різних лікарських препаратів та доведена можливість використання розроблених методик для аналізу існуючих лікарських препаратів на основі диклофренаку натрію.

\section{РАЗРАБОТКА ОРИГИНАЛЬНОЙ МЕТОДИКИ ОПРЕДЕЛЕНИЯ ДИКЛОФЕНАКА НАТРИЯ В РАЗЛИЧНЫХ ФОРМАХ ЛЕКАРСТВЕННЫХ ПРЕПАРАТОВ \\ В.А.Ханин, А.М.Котенко, А.А.Моисеев, А.В.Доровской}

Ключевые слова: диклофенак натрия; высокоэффрективная жидкостная хроматография; количественное определение; валидация

Существует ряд методик определения диклофенака натрия в лекарственных средствах, однако все они различаются задействованными аналитическими методами в зависимости от лекарственной формы препарата. Целью данного исследования стала разработка универсальной ВЭЖХ- методики определения диклофенака натрия, которая была бы пригодна для количественного определения этого АФИ в различных лекарственных форммах. B исследованиях использован хроматографо 2695 с диодноматричным детектором 2996 фрирмы Waters Corp. USA с колонкой, содержащей фразу C18 с размером частии 5 мм, весы ER-182 формы AND Japan, мерная посуда класса A. Валидация методики проводилась в соответствии с требованиями ГФУ. Разработана ВЭЖХ-методика определения диклофенака натрия в различных лекарственных формах и UPLC-вариант этой методики для проведения экспресс-измерений. Проведена валидация предложенных методик, доказана их пригодность для определения диклофенака натрия в различных лекарственных формах и незначимое влияние пробоподготовки на результат анализа. Выполнен анализ различных лекарственных средств и доказана возможность использования разработанных методик для анализа существующих лекарственных средств на основе диклофенака натрия. 